\title{
An epiphytacean-Girvanella (Cyanobacteria) symbiosis from the Cambrian (Series 3; Drumian) of North Greenland (Laurentia)
}

John S. Peel

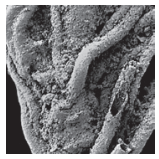

\begin{abstract}
The widespread Cambrian calcareous cyanobacterium Girvanella is described in symbiotic association with a new epiphytacean, Orpikania freucheni gen. et sp. nov. (Microproblematica), from the Ekspedition Bræ Formation (Cambrian Series 3, Drumian Stage) of Freuchen Land, North Greenland. The phosphatized assemblages preserve dendrites of the epiphytacean forming a supporting framework for discrete climbing filaments of Girvanella lianiformis sp. nov. that are firmly attached to their host with holdfasts. Elevation of the slender Girvanella filaments on the framework of the dendrite potentially enhanced their phototactic movement towards the light. Filaments in the co-occurring Girvanella pituutaq sp. nov. are regularly twisted together into a rope-like form which may have assisted elevation above its substrate. - Key words: Cambrian, Drumian, Cyanobacteria, epiphytacean, symbiosis, North Greenland.
\end{abstract}

Peel, J.S. 2018. An epiphytacean-Girvanella (Cyanobacteria) symbiosis from the Cambrian (Series 3, Drumian) of North Greenland (Laurentia). Bulletin of Geosciences 93(3), 327-336 (3 figures). Czech Geological Survey, Prague. ISSN 1214-1119. Manuscript received February 2, 2018; accepted in revised form May 25, 2018; published online July 3, 2018; issued August 20, 2018.

John S. Peel, Department of Earth Sciences (Palaeobiology), Uppsala University, Villavägen 16, SE-75236 Uppsala, Sweden; john.peel@pal.uu.se

Cyanobacteria have existed for more than 3.5 billion years (Schopf \& Klein 1992, Schopf 2012), while the geological range of algae extends back at least $1.6 \mathrm{Ga}$ (Bengtson et al. 2017). It is first as the Phanerozoic is approached, however, that calcification becomes prominent in both groups, although the affinity of many of the numerous described Cambrian taxa is uncertain (Riding 1991). The great majority of published studies of these Cambrian calcified forms were carried out by Russian palaeontologists working with thin sections from carbonate rocks (Maslov 1956; Korde 1959, 1961, 1973; Voronova 1976; Drozdova 1980; Luchinina 1995 and others noted in the historical summary by Riding 1991). Descriptions of Cambrian material based on other modes of preservation are uncommon, although phosphatized cyanobacterial remains are not rare in residues resulting from the dissolution of carbonates in acetic acid (Luchinina \& Tikhomirova 1988; Peel 1988; Qian \& Bengtson 1989; Bengtson et al. 1990; Wrona 2004). By contrast, phosphatized microfossils have been employed routinely together with thin sections in the description of fossil assemblages from the Ediacaran Doushantuo Formation of South China (Cunningham et al. 2015, 2017; Muscente et al. 2015). When etched free from matrix, such material provides three-dimensional information not readily available from thin section studies, although modern $\mathrm{X}$-ray tomography provides a complementary technique of growing importance (Cunningham et al. 2015, Bengtson et al. 2017).

In a Laurentian context, phosphatized oscillatoriacean cyanobacteria from the Portfjeld Formation (ProterozoicCambrian boundary) of North Greenland show two contrasting styles of phosphatization (Peel 1988). Naked trichomes assigned to Jiangispirellus groenlandicus Peel, 1988 preserve internal moulds of individual cells, seemingly as a result of phosphatization of bacteria within the cell wall prior to degradation. Co-occurring specimens assigned to Spirellus shankari (Singh \& Shukla 1981) are preserved as phosphatized sheaths without evidence of the enclosed trichome and its cells. The filaments show phosphatized smooth, unmineralized, sheaths alongside morphologies in which the sheaths are variably calcified or overgrown by calcification prior to the initiation of phosphatization, as well as various stages in filament degradation prior to phosphatization (Peel 1988). Qian \& Bengtson (1989) placed Jiangispirellus as a junior synonym of Spirellus Jiang in Luo et al., 1982, but the genus was maintained by Knoll (1992) and Mankiewicz (1992a). Systematic opinions aside, the potential value of studying phosphatized material is demonstrated by 
these co-occurring different styles of preservation and preservational histories.

This paper describes phosphatized specimens of cyanobacteria-like fossils from the Ekspedition Bræ Formation of North Greenland (Cambrian Series 3, Drumian Stage; Fig. 1). They represent two of the most common Cambrian morphotypes: a multi-axial dendritic epiphytacean (Microproblematica) described as Orpikania freucheni gen. et sp. nov., and slender unbranched filaments of Girvanella Nicholson \& Etheridge 1878 (Cyanobacteria; Fig. 2). In addition to contributing new morphological and preservational information, the assemblage documents a symbiotic relationship between the dendrite and the climbing filaments of Girvanella.

\section{Material and methods}

GGU samples 315118 and 315119 were collected from the basal $0.5 \mathrm{~m}$ of the Ekspedition Bræ Formation (Cambrian Series 3, Drumian) by J.S. Peel on 22nd July 1984 on a nunatak in southern Freuchen Land, east of the head of Nordenskiöld Fjord $\left(82^{\circ} 09^{\prime} 10^{\prime \prime} \mathrm{N}, 42^{\circ} 24^{\prime} \mathrm{W}\right.$; Fig. 1). The limestone samples were dissolved in $10 \%$ acetic acid and hand-picked. Selected phosphatized specimens from the residues were gold-coated prior to stereoscan microscopy; images were assembled in Adobe Photoshop CS4. Unfortunately, comparative thin section studies were not possible since all available sample material was dissolved in acid during the preparation process.

The Ekspedition Bræ Formation was deposited during a sea-level lowstand within the Cambrian-Early Ordovician carbonate-dominated, northward prograding, shelf margin complex of central and eastern North Greenland (Higgins et al. 1991, Ineson \& Peel 1997). It consists mainly of pale-weathering, thin-bedded, grey lime mudstones and skeletal wackestones that are interbedded with grey-green calcareous mudstones, and forms recessive pale weathering slopes between cliffforming dolostone formations below and above (Ineson \& Peel 1997). The formation attains a thickness of $82 \mathrm{~m}$ at the type locality in eastern Lauge Koch Land but thins to the west across southern Freuchen Land, becoming dominantly argillaceous (Ineson \& Peel 1997).

The age of the Ekspedition Brae Formation was discussed by Geyer \& Peel (2017). Robison, R.A. (written communication 1987, cited by Peel \& Streng 2015) dated the current samples to the Ptychagnostus atavus Biozone, the basal zone of the Drumian Stage (Cambrian Series 3, Stage 6), equivalent to the lower part of the Bolaspidella Biozone of the American standard (Babcock et al. 2007).

Institutional abbreviations. - GGU indicates a sample made during regional geological campaigns of Grønlands
Geologiske Undersøgelse (Geological Survey of Greenland). Type and figured specimens are deposited in the palaeontological type collection of the Museum of Evolution, Uppsala University (PMU prefix), Uppsala, Sweden, and the Natural History Museum of Denmark, Copenhagen (MGUH prefix).

\section{Systematic palaeontology}

Microproblematica

Family Epiphytaceae Korde, 1959

Discussion. - Epiphytaceans are small, heavily calcified, dendritic fossils that are common in Cambrian limestones but also occur sporadically in younger strata (Riding 1979, 1991; Riding \& Voronova 1982; Săsăran et al. 2014; Liu et al. 2016). Riding (1991) noted that epiphytaceans have been considered to be chlorophytes, rhodophytes or cyanobacteria, although he favoured the latter. Luchinina (1995, p. 12) placed them within a group Calciobionta, "an independent subdivision of fossil algae with no modern analogues", but Luchinina \& Terleev $(2008,2014)$ assigned Epiphyton Bornemann, 1886 to the rhodophytes (red algae). In reviewing their distribution from Cambrian to Cretaceous, Săsăran et al. (2014) concluded that epiphytaceans were likely cyanobacteria but probably a heterogeneous group. Liu et al. (2016) considered Epiphyton to Microproblematica and this view is followed here.

More than 100 species assigned to Epiphyton were listed by Guiry (2018; see also Mankiewicz 1992b), too many according to Riding (1991) with specific reference to Korde (1961). Riding (1991) also questioned the proliferation of genera within the Epiphyton group proposed by Korde (1973), focusing his discussion on four bush-like genera which he considered well established: Epiphyton, Korilophyton, Gordonophyton and Tubomorphophyton. Epiphyton was considered to be solid, micritic and dendritic in form, while Korilophyton Voronova, 1976 had only short branches. Gordonophyton Korde, 1973 was larger, with transverse chamber-like gaps in the threads, and often with the filaments expanding in diameter distally. Tubomorphophyton Korde, 1973 was like Epiphyton but had tubiform branches (Riding \& Voronova 1982).

The description by Luchinina \& Terleev (2008) of abundant transverse structures within the branches of Epiphyton durum Korde, 1961 and E. induratum Korde, 1961 from the Cambrian (Series 2) of Siberia seemed to demonstrate the close similarity of Epiphyton to Gordonophyton, and separation of the genera on that criterion alone is no longer possible. Korde (1973, p. 198) had referred E. durum to Gordonophyton, as did Drozdova 

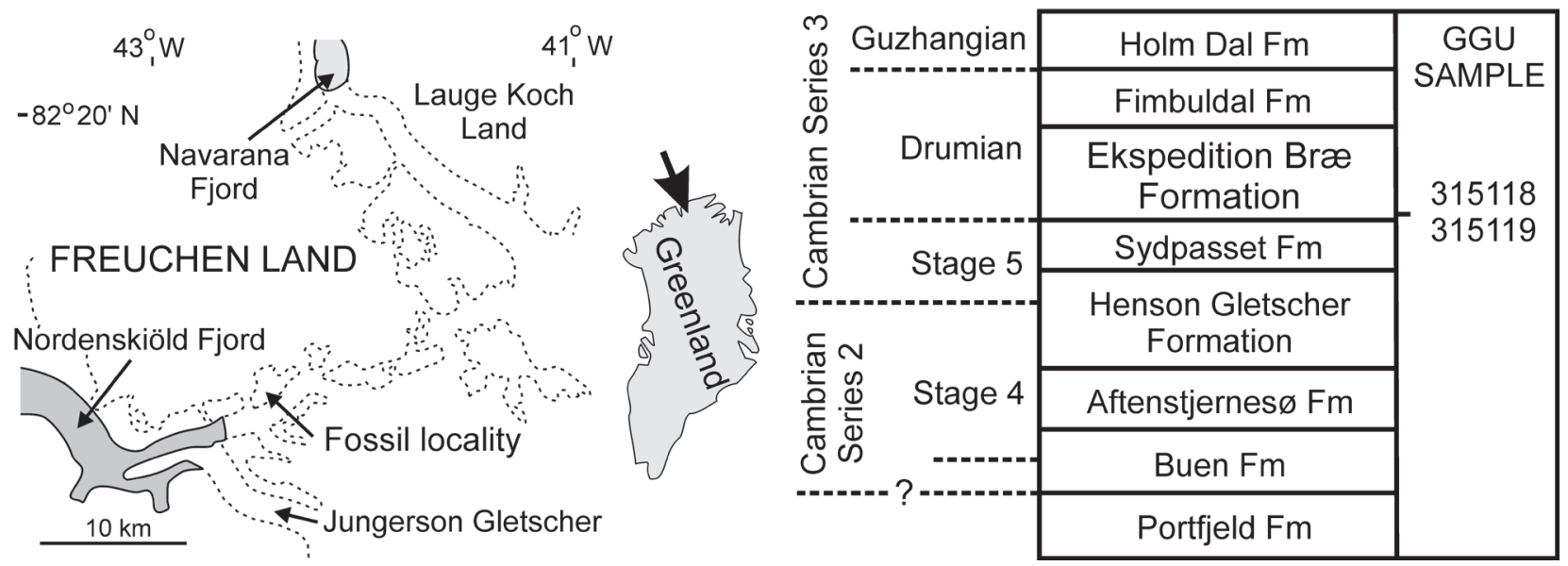

Figure 1. Derivation of fossiliferous samples from the Ekspedition Bræ Formation, southern Freuchen Land, North Greenland.

(1980, p. 80; see also Zhuravlev et al. 2011), while Luchinina (1995) and Luchinina \& Terleev (2008) gave no discussion of Gordonophyton. Riding (1991) noted, however, that Gordonophyton might be distinguished from Epiphyton by the distal increase in diameter of the branches. Transverse structures have also been described by Săsăran et al. (2014) in a Jurassic epiphytacean from Romania, but differ from those described in Epiphyton durum, E. induratum and Gordonophyton in being concave up.

Transverse structures are also described in the new genus of dendritic epiphytacean from the Ekspedition Bræ Formation described below and are interpreted as a representation of cells in the trichome.

\section{Genus Orpikania gen. nov.}

Type species. - Orpikania freucheni sp. nov. from the Ekspedition Bræ Formation (Cambrian Series 3, Drumian Stage) of North Greenland.

Etymology. - From 'orpik', the Greenlandic word for tree, reflecting the dendritic habit.

Diagnosis. - Multi-axial epiphytacean with cylindrical dichotomous branches about $100 \mu \mathrm{m}$ in diameter and with points of branching about $1 \mathrm{~mm}$ apart. Cell height about half of filament width; mineralized sheath thin, reflecting the underlying cell structure.

Discussion. - Orpikania differs from Epiphyton and Gordonophyton in the greater relative height of the presumed cells in the filaments. In Gordonophyton, the height of the cells is $20-25 \%$ of their width (Korde 1973, figs 21,22$)$, compared with about $50 \%$ in Orpikania. Demoulin \& Janssen (1981) noted that the relative height of cells in cyanobacterial filaments tends to decrease as the diameter of the filaments increases, but the diameter of filaments in Orpikania (about $100 \mu \mathrm{m}$ ) is about 30\% greater than Gordonophyton. Cell size is variable in E. durum of Luchinina \& Terleev (2008), but generally less than $20 \%$; some cell layers are reported to have a height of only $2-4 \mu \mathrm{m}$ in filaments that are $42-70 \mu \mathrm{m}$ in diameter. As noted by Riding (1991), most described specimens of Epiphyton are dense and micritic, lacking indications of internal structure. The dendrites are usually small, with narrower filaments and more closely spaced branching points than in Orpikania (Korde 1961, 1973). The difficulty of comparing such material to the relatively well preserved Greenland material is an added reason to propose Orpikania freucheni.

Orpikania has a similar branching style to Ramitubus increscens Liu et al., 2008, described on the basis of phosphatized specimens etched from carbonates of the Ediacaran Weng'an Biota (Doushantuo Formation, Ediacaran) of South China (Liu et al. 2008, pl. 1, figs 1, 2). In the illustrated holotype of $R$. increscens, the diameter of the branches is about $100 \mu \mathrm{m}$, comparable to Orpikania, but much larger specimens are known. Branches are divided into prominent, stacked, cell-like compartments, about $10-15 \mu \mathrm{m}$ high, by regular cross walls (Cunningham et al. 2015). A thin outer wall to the filament may be present, and filaments may show periodic growth interruptions (Liu et al. 2008, pl. 1, fig. 6). The affinity of Ramitubus increscens and other tubes from the Weng'an Biota is problematic and they have been compared to cnidarians, cyanobacteria and algae (Cunningham et al. 2015). The rigidity of the cross walls may argue against their interpretation as cell walls, while the diameter of the compartments in the largest specimens (up to $625 \mu \mathrm{m}$ in Ramitubus) far exceeds the filament width of living cyanobacteria (Cunningham et al. 2015). 
However, Cunningham et al. (2015) favoured an algal rather than cnidarian relationship.

Other species. - Type species only.

\section{Orpikania freucheni sp. nov.}

Figure 2B-E, H-J, N

Holotype. - PMU 31759 from GGU sample 315119 (Fig. 2B, C).

Paratypes. - PMU 31761, PMU 31763-31765, PMU

31767, PMU 31768 from GGU sample 315119.

Type horizon and locality. - Ekspedition Bræ Formation (Cambrian Series 3, Drumian Stage) of southern Freuchen Land, North Greenland (Fig. 1).

Material. - Except types about 10 fragments from GGU samples 315118 and 315119.

Etymology. - For Peter Freuchen (1886-1957), Danish author, adventurer and arctic explorer, after whom Freuchen Land was named.

Diagnosis. - As for genus.

Description. - The overall form and size of the multiaxial dendritic thallus is not known but fragments of the branches attain a maximum observed length of $2 \mathrm{~mm}$ (Fig. 2H). The branches are cylindrical, typically $90-100 \mu \mathrm{m}$ in diameter, but this may increase prior to the formation of new branches. New branches are often narrower than the parent branch, at least initially (Fig. $2 \mathrm{~N}$, arrow). After their original divergence, new branches most commonly grow parallel to the 'parent' branch (Fig. $2 \mathrm{C}, \mathrm{E}, \mathrm{H})$, but divergence at up to 30 degrees is observed (Fig. 2J). Change in curvature in the latter specimen suggests that it may have occupied a lateral position in the thallus whereas forms with parallel branches were located in more central areas. New branches arise at an interval of about $1 \mathrm{~mm}$, diverging laterally from the parent branch rather than by simple bifurcation (Fig. 2N, arrow). Branches are transversely annulated in segments, the length of which is about half the diameter of the branch. Boundaries between consecutive segments, interpreted as cells within the trichome, are grooved; their lateral profile is shouldered at the sutures, but shallowly concave between. The mineralized sheath is seemingly thin since cell wall sutures are visible, but it also thins distally along the branches.

Discussion. - The holotype of Orpikania freucheni sp. nov. clearly demonstrates the incised transverse sutures interpreted as indicating cell walls (Fig. 2C), indicating that the mineralized sheath was very thin. However, the presence of a mineralized sheath during life, as distinct from a feature of postmortal mineralization, is indicated by the repaired transverse fracture affecting both filaments (Fig. 2C, arrow). The sheath was likely mineralized with amorphous calcium carbonate, as is the case with contemporaneous cyanobacteria and similar fossils (Riding 1991). Fractures representing diagenetic compaction are present in other specimens (Fig. 2H).

The walls of the tubular filaments, as preserved, are about $5 \mu \mathrm{m}$ thick and details of the interior are not preserved (Fig. 2B). Proximal tapering of internal moulds of the tube in some specimens indicates that the wall may have been thicker in the proximal part of filaments (Fig. 2I). Holes in the walls of some specimens may result from holdfasts of Girvanella lianiformis gen. et sp. nov. breaking away from their host (Fig. 2E). Several specimens show deformation of distal extremities suggesting that these may have been unmineralized, or only weakly mineralized, in life (Fig. 2H, arrow). This is supported by distal degradation of filaments (Fig. 2L, arrows) where the degraded portion was clearly phosphatized postmortem. While annulation on the external surface of the mineralized sheaths indicates the presence of cells in the trichome, the nature of the trichome itself is not known; it was presumably composed of organic material which has not survived diagenesis.

Branching usually results in sub-equal filaments (Fig. 2E, H, J), with one branch displaced slightly to one side, but narrower branches may result (Fig. $2 \mathrm{~N}$, arrow). In the holotype (Fig. 2B, C), the narrowness of the central branch of the three distal branches appears to result from the breakage of the specimen in life. The original central

Figure 2. Cyanobacteria and Epiphytaceae from the Ekspedition Bræ Formation, southern Freuchen Land; GGU sample 315119. • A - Girvanella pituutaq sp. nov., PMU 31758, holotype. • B, C, E, H-J, L-N - Orpikania freucheni gen. et sp. nov.; B, C - PMU 31759, holotype, arrow indicates premortal repaired fracture; E - PMU 31761; H - PMU 31763, arrow indicates phosphatized but un-mineralized sheath; I - PMU 31764, branching fragment with internal mould (below) and annulated mineralized sheath (above); J, M - PMU 31765, branching fragment with attached Girvanella freucheni sp. nov. showing detail of distal termination (M); L - PMU 31767, fragment with degraded filament (arrows); N - PMU 31768, showing recent branch (arrow). D, F, G, J, K, O, P - Girvanella freucheni sp. nov.; D - PMU 31760, filaments on branching Orpikania freucheni gen. et sp. nov., with holdfasts (arrows); F, G - PMU 31762, holotype, with holdfasts (arrows in G, detail in F); J - PMU 31765, on Orpikania freucheni gen. et sp. nov.; K - PMU 31766, tangled filaments on branch of Orpikania freucheni gen. et sp. nov., with holdfasts (arrows); O, P - PMU 31769 tangled filaments with holdfast (P, arrow) and detail of broken transverse surface showing layering $(\mathrm{O})$. Scale bars: $100 \mu \mathrm{m}$, except $\mathrm{M}(50 \mu \mathrm{m})$ and $\mathrm{O}(20 \mu \mathrm{m})$. 


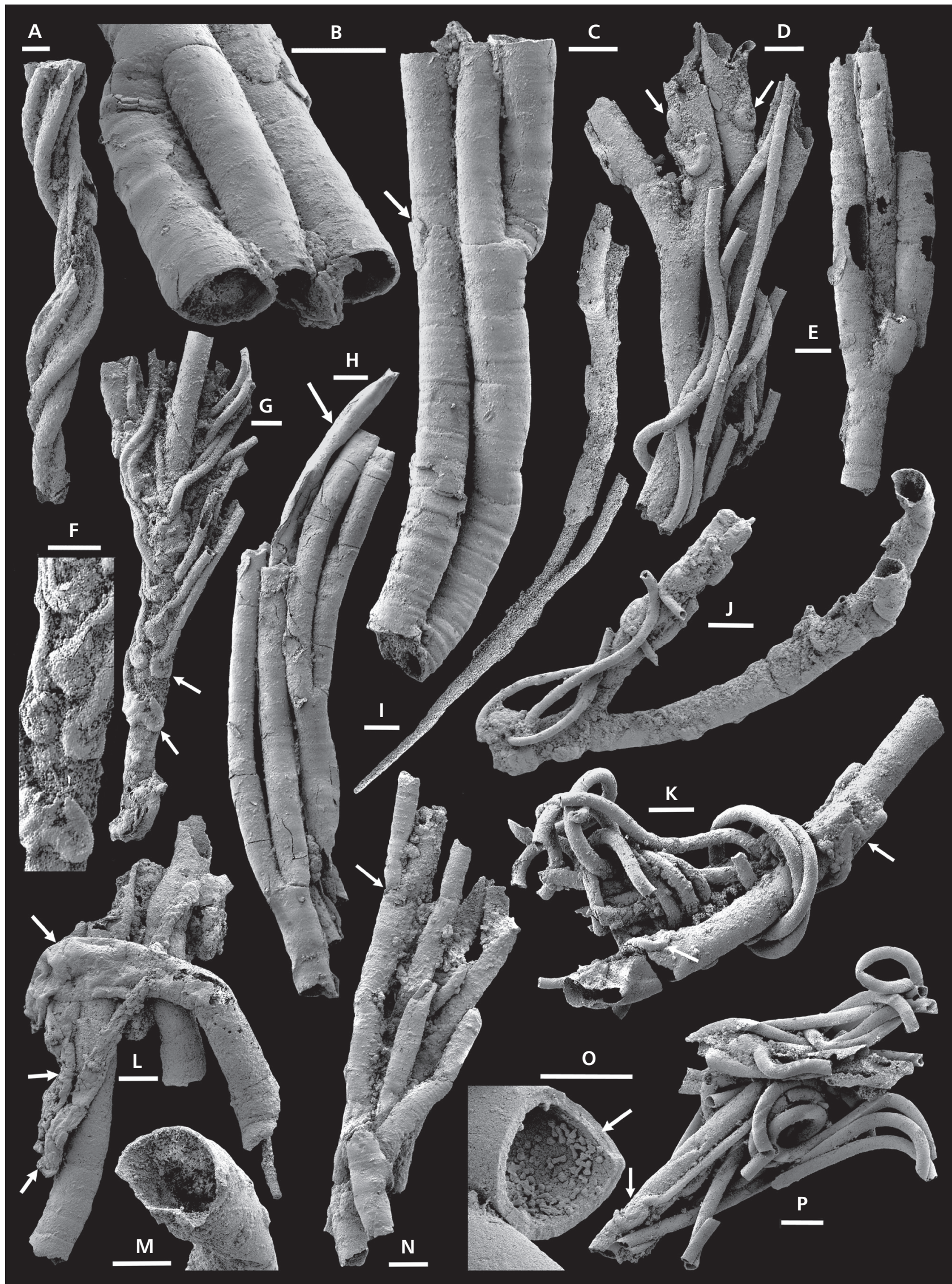


branch was apparently broken away, leaving a clear transverse scar, such that the original side-branch (right in Fig. 2C) has a greater diameter than the replacement central branch.

In its general form, Orpikania freucheni sp. nov. resembles Epiphyton frondosum Korde, 1961, as illustrated by Luchinina (1995) from the Usa Formation (Cambrian Series 2, Atdabanian) of the Kiya River Basin in Siberia, although stated to range into Cambrian Series 3. It is distinguished from this species, and others described by Luchinina (1995), Korde $(1961,1973)$ and Drozdova (1980) by the greater diameter of its branches (about $100 \mu \mathrm{m}$ compared to $70 \mu \mathrm{m}$ in E. frondosum) and the spacing of the branching points (100 $\mu \mathrm{m}$ compared to $300-500 \mu \mathrm{m}$ in E. frondosum). Gordonophyton distinctum Korde, 1973 is distinguished by branches which increase in width distally (Riding 1991, fig. 4g), attaining a diameter of about $70 \mu \mathrm{m}$.

Phylum Cyanobacteria Stanier, 1974

Family Cyanophyceae Schaffner, 1909, incertae sedis

\section{Genus Girvanella Nicholson \& Etheridge, 1878}

Type species. - Girvanella problematica Nicholson \& Etheridge, 1878, from the Upper Ordovician Stinchar Limestone, Girvan, southern Scotland.

Discussion. - Type material of Girvanella was described by Wood (1957) and Danielli (1981), with Danielli (1981) noting that the thin-walled tubular filaments of most described species have an internal diameter in the range 10-25 $\mu \mathrm{m}$. Mamet \& Roux (1975) proposed reduction of the more than 20 described species to just four, based on the diameter of the filaments, although Danielli (1981) commented that this did not agree well with the range seen in the type material (Wood 1957). Liu et al. (2016) followed Mamet \& Roux (1975), but their material is more slender (diameter less than $28 \mu \mathrm{m}$ ) than that described here. Riding (1991) suggested that Nicholsonia Korde, 1973 might be a useful name for specimens with greater tube widths but Liu et al. (2016) followed Danielli (1981) in considering this to be a junior synonym of Girvanella.

\section{Girvanella lianiformis sp. nov.}

Figure 2D, F, G, J, K, O, P

Holotype. - PMU 31762 from GGU sample 315119 (Fig. 2F, G).

Paratypes. - PMU 31760, PMU 31765, PMU 31766, PMU 31769 from GGU sample 315119.

Type horizon and locality. - Ekspedition Bræ Formation
(Cambrian Series 3, Drumian Stage) of southern Freuchen Land, North Greenland (Fig. 1).

Material. - Except types about 15 specimens from GGU samples 315118 and 315119.

Etymology. - From the resemblance to the lianas, climbing vines, of present day tropical deciduous forests which use trees to support their climb upwards towards the light.

Diagnosis. - Cylindrical filaments about $40 \mu \mathrm{m}$ in external diameter, single or loosely tangled; attached to substrate with a curved or sinuous holdfast.

Description. - As preserved, the filaments consist of smooth-walled, parallel-sided, tubes about $40 \mu \mathrm{m}$ in diameter which are attached to Orpikania branches by curved or sinuous holdfasts (Fig. 2C, F, G, P). The filament walls are about $5 \mu \mathrm{m}$ thick and may show several layers (Fig. 2O, arrow); internal structures are not preserved. Filaments are initially relatively straight or slightly sinuous as they progress from their holdfast towards more distal regions of the Orpikania thallus (Fig. 2D, G, J) but open tangles quickly develop (Fig. 2K, P). The holdfasts may be tightly coiled (Fig. 2D, arrows; $2 \mathrm{~F}, \mathrm{G}$ arrows) or sinuous (Fig. 2P, arrow), and are attached over a distance of $20-50 \mu \mathrm{m}$.

Discussion. - Most described material of Girvanella consists of dense tangles of tubes (Fig. 3) unlike the isolated threads with holdfasts and loose coils of Girvanella lianiformis sp. nov. from the Ekspedition Bræ Formation. The difference in style is seen as a reflection of the phototactic growth of the threads in the symbiosis with Orpikania freucheni.

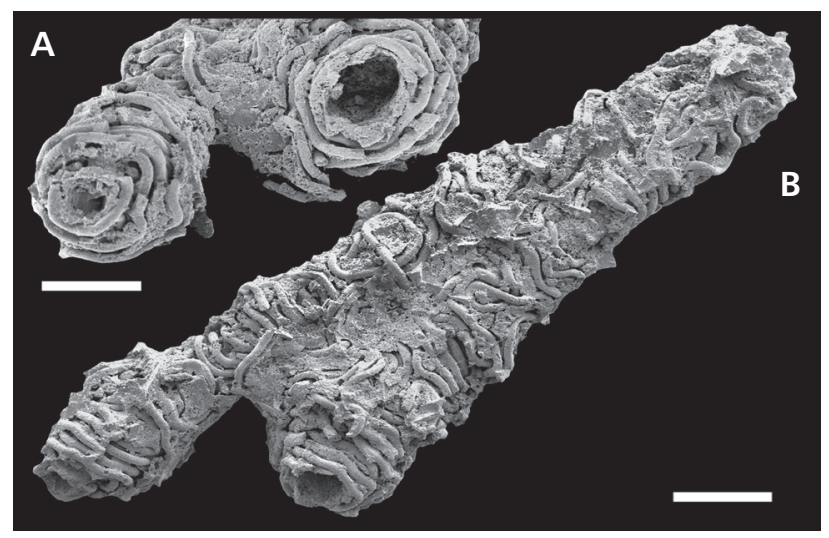

Figure 3. Girvanella sp., phosphatized specimen tightly wound around an unknown (algal?) substrate; associated with MGUH 27652 from GGU sample 271718. Uppermost $1 \mathrm{~m}$ of the Henson Gletscher Formation (Cambrian Series 3, Stage 5, Ptychagnostus gibbus Biozone. Løndal, Peary Land (82 $17.5^{\prime} \mathrm{N}, 37^{\circ} 03^{\prime} \mathrm{W}$; Peel 2017, fig. 1) about $70 \mathrm{~km}$ east of current locality. Scale bar: A, $60 \mu \mathrm{m}, \mathrm{B}, 100 \mu \mathrm{m}$. 
The holotype of Girvanella lianiformis preserves numerous coiled or serpentiform holdfasts which indicate redirection of the developing filaments as they seek distally, presumably towards the light (Fig. 2F, G). In some other specimens the filaments quickly form a loose tangle (Fig. $2 \mathrm{~K}, \mathrm{P}$ ) but this is unlike the tightly packed filaments of the specimen from the Henson Gletscher Formation and other described species (Fig. 3). In the holotype there is a tendency for the filaments of Girvanella lianiformis to twist together into ropes distally (Fig. 2G).

\section{Girvanella pituutaq sp. nov.}

Fig. 2A

Holotype. - PMU 31758 from GGU sample 315119 (Fig. 2A).

Type horizon and locality. - Ekspedition Bræ Formation (Cambrian Series 3, Drumian Stage) of southern Freuchen Land, North Greenland (Fig. 1).

Material. - Holotype and two additional specimens.

Etymology. - From 'pituutaq', the Greenlandic word for rope, alluding to the twisting together of the filaments.

Diagnosis. - Thin-walled, cylindrical filaments, about $60-80 \mu \mathrm{m}$ in external diameter, regularly twisted together into a rope.

Description. - The holotype is a fragment with a length of about $1.7 \mathrm{~mm}$ and a width of about $250 \mu \mathrm{m}$. It is sinuous in form on account of the twisting together of four or five thin-walled filaments, with each filament making about one revolution around the longitudinal axis in the available fragment. Individual filaments are of uniform width, between $60 \mu \mathrm{m}$ and $80 \mu \mathrm{m}$ in diameter.

Discussion. - Two additional specimens are known from the same sample as the holotype, one of which has narrower filaments than the holotype. On account of the rarity of available material the species is conservatively retained in Girvanella. Prostrate bunches of parallel filaments characterize Subtifloria delicata Maslov, 1956 and Batenevia ramosa Korde, 1973 but the present filaments are much thicker, fewer in number, and more strongly twisted. A semblance of spiral twisting seen in the most distal parts of the holotype of Girvanella lianiformis (Fig. 2G) suggests that twisting of the filaments in G. pituutaq may provide a method of self-support possibly developed beyond the upper surface of the Orpikania thallus. However, the diameter of the filaments in the illustrated specimen of G. pituutaq is substantially greater than described filaments of Girvanella lianiformis.

\section{Symbiosis}

At the present day, numerous symbioses exist involving cyanobacteria and similar encrusting organisms and a wide range of other life forms. The symbioses may be complex, encompassing defence, camouflage, nutrition and other biochemical interactions (Adams, 2000, Adams et al. 2012, Grube et al. 2017), but also neutralistic, without clear benefit or detriment to either party. In many epiphytic symbioses, the benefit to the encrusting epibiont may be restricted just to the provision by the basibiont of a suitable attachment site on the substrate organism. Vinn (2017) reviewed a variety of symbioses between Cambrian macrofossils, including symbioses between frondose alga-like organisms and brachiopods (Wang et al. 2012) and archaeocyath-algal associations (Rowland \& Gangloff 1988, Gandin \& Debrenne 2010, McMenamin 2016).

The symbiosis between Orpikania freucheni and Girvanella lianiformis in the Ekspedition Bræ Formation seemingly reflects a simple host-epibiont relationship. There is no apparent advantage to the host Orpikania whereas positioning of the slender Girvanella filaments on the robust framework of the multi-axial Orpikania elevated their attachment and potentially enhanced phototactic movement towards the light. In this sense, this commensal symbiosis is similar to that involving Girvanella and an unknown, probably algal, host from the upper Henson Gletscher Formation (Fig. 3), although this differs in the intensity of the Girvanella overgrowth.

Epiphytacean encrustation may occur on surfaces of any orientation, or within cavities, so that the direction of growth of the thallus may be equally upwards or downwards (Kobluk \& James 1979, Adachi et al. 2015). Whatever the orientation, filaments of Girvanella lianiformis probably benefitted from extending their growth zone beyond that of the host Orpikania. The spiral twisting together of filaments in the co-occuring Girvanella pittutaq sp. nov. may have achieved a similar aim, with the bundles of filaments offering mutual support. However, the few available specimens offer no clear indication of a direct symbiotic relationship with Orpikania.

Epiphytes also attach to inorganic or dead organic substrates and it may be difficult to determine if the latter were alive (i.e. in symbiosis) or dead at the time (Peel 2014, 2017). The proposed symbiosis between Orpikania freucheni and Girvanella lianiformis implies that both species grew at the same time, although Orpikania freucheni must have first provided the framework which supported the slender thalli of Girvanella lianiformis. Strong evidence that Girvanella lianiformis encrusted living specimens of Orpikania freucheni is provided by the shared alignment of thalli (Fig. 2D, G) and in the change 
in orientation of attached threads of Girvanella lianiformis made to achieve this (Fig. 2F). Growth of Girvanella lianiformis does not occur in a random direction as might be expected if the specimens of Orpikania freucheni were simply bioclasts on the sea floor. Furthermore, attached threads or holdfasts of Girvanella lianiformis have not been found on other members of the fossil association in GGU samples 315118 and 315119. Evidence of Girvanella lianiformis living on dead Girvanella lianiformis, such as transgressing broken surfaces or apertures is also lacking.

\section{Acknowledgements}

Samples were collected during the North Greenland Project (1984-1985) of Grønlands Geologiske Undersøgelse (GGU; Geological Survey of Greenland, now a part of the Geological Survey of Denmark and Greenland (GEUS), Copenhagen. Sebastian Willman (Uppsala) is thanked for discussion of the manuscript. Jean-Paul Saint Martin (Paris), an anonymous reviewer and journal editorial staff are acknowledged for comments on the manuscript.

\section{References}

Adachi, N., Kotani, A., Ezaki, Y. \& LiU, J. 2015. Cambrian Series 3 lithistid sponge-microbial reefs in Shandong Province, North China: reef development after the disappearance of archaeocyaths. Lethaia 48, 405-416. DOI 10.1111/let.12118

Adams, D.G. 2000. Symbiotic interactions, 523-561. In Whitton, B.A. \& Potts, M. (eds) The ecology of Cyanobacteria. Kluwer Academic Publishers, New York.

Adams, D.G., Duggan, P.S. \& JaCKson, O. 2012. Cyanobacterial symbioses, 594-647. In Whitton, B.A. (ed.) Ecology of Cyanobacteria II: their diversity in time and space. Springer, Dordrecht.

Babcock, L.E., Robison, R.A., Rees, M.N., Peng, S. \& Saltzman, M.R. 2007. The global boundary stratotype section and point (GSSP) of the Drumian Stage (Cambrian) in the Drum Mountains, Utah, USA. Episodes 30, 84-94.

Bengtson, S., Conway Morris, S., Cooper, B.J., Jell, P.A. \& RunNegar, B.N. 1990. Early Cambrian fossils from Australia. Memoir of the Australasian Association of Palaeontologists 9, 1-364.

Bengtson, S., Sallstedt, T., Belivanova, V. \& Whitehouse, M. 2017. Three dimensional preservation of cellular and subcellular structures suggests 1.6 billion-year-old crowngroup red algae. PLOS Biology 15(3) e2000735, 1-38. DOI 10.1371/journal.pbio.2000735

Bornemann, J.G. 1886. Die Versteinerungen des Cambrischen Schichten-systems der Insel Sardinien nebst vergleichenden Untersuchungen über analogue Vorkommnisse aus andern Ländern. Nova Acta der Kaiserlichen LeopoldinischCarolinischen Deutschen Akademie der Naturforschung 51(1), 1-147.
Cunningham, J.A., Vargas, K., Liu, P., Belivanova, V., Marone, F., Martínez-Pérez, C., Guizar-Sicairos, M., Holler, M., Bengtson, S. \& Donoghue, P.C.J. 2015. Critical appraisal of tubular putative eumetazoans from the Ediacaran Weng'an Doushantuo biota. Proceedings of the Royal Society of London B 282, 1-9.

DOI 10.1098/rspb.2015.1169

Cunningham, J.A., Vargas, K., Yin, Z., Bengtson, S. \& Donoghue, P.C.J. 2017. The Weng'an Biota (Doushantuo Formation): an Ediacaran window on soft-bodied and multicellular microorganisms. Journal of the Geological Society 174, 793-802. DOI 10.1144/jgs2016-142

DANIELli, C.M. 1981. The fossil alga Girvanella Nicholson and Etheridge. Bulletin of the British Museum of Natural History, Geology Series 35(2), 1-107.

Demoulin, V. \& Janssen, M.P. 1981. Relationship between diameter of the filament and cell shape in blue-green algae. British Phycological Journal 16, 55-58. DOI 10.1080/00071618100650051

Drozdova, N.A. 1980. Vodorosli v organogennykh postrojkakh nizhnego Kembriya Zapadnoy Mongolii. Trudy Sovmestnoy Sovetsko-Mongol'skoy Paleontologicheskoy Ekspeditsii 10, $1-140$.

Gandin, A. \& Debrenne, F. 2010. Distribution of the archaeocyath-calcimicrobial bioconstructions on the early Cambrian shelves. Palaeoworld 19, 222-241. DOI 10.1016/j.palwor.2010.09.010

Geyer, G. \& Peel, J.S. 2017. Middle Cambrian trilobites from the Ekspedition Bræ Formation of North Greenland, with a reappraisal of the genus Elrathina. Journal of Paleontology 91, 265-293. DOI 10.1017/jpa.2016.152

Grube, M., Seckbach, J. \& Muggia, L. (eds) 2017. Algal and Cyanobacteria symbioses. 644 pp. World Scientific Europe, London. DOI 10.1142/q0017

Guiry, M.D. 2018. Epiphyton. In Guiry, M.D. \& Guiry, G.M. (eds) AlgaeBase. Worldwide electronic publication, National University of Ireland, Galway. http://www. algaebase.org

Higgins, A.K., Ineson, J.R., Peel, J.S., Surlyk, F. \& SønderHOLM, M. 1991. Lower Palaeozoic Franklinian Basin of North Greenland. Grønlands Geologiske Undersøgelse Bulletin 160, 71-139.

Ineson, J.R., \& PeEL, J.S. 1997. Cambrian shelf stratigraphy of North Greenland. Geology of Greenland Survey Bulletin 173, $1-120$.

KNOLL, A.H. 1992. Vendian microfossils in metasedimentary cherts of the Scotia Group, Prins Karls Forland, Svalbard. Palaeontology 35, 751-774.

KoBluK, D.R. \& JAmEs, N.P. 1979. Cavity-dwelling organisms in Lower Cambrian patch reefs from southern Labrador. Lethaia 12, 193-218. DOI 10.1111/j.15023931.1979.tb00997.x

Korde, K.B. 1959. Morfologiya i sistematicheskoe polozhenie predstavitelei roda Epiphyton. Doklady Akademii Nauk SSSR 126, 1087-1089.

KorDE, K.B. 1961. Vodorosli kembriya yugo-vostoka Sibirskoy platformy. Akademija Nauk SSSR, Trudy Paleontologitscheskogo Instituta 89, 1-148. 
Korde, K.B. 1973. Vodorosli Kembriya. Akademija Nauk SSSR, Trudy Paleontologitscheskogo Instituta 139, 1-349.

Liu, L., Wu, Y., YAnG, H. \& Riding, R. 2016. Ordovician calcified cyanobacteria and associated microfossils from the Tarim Basin, Northwest China: systematics and significance. Journal of Systematic Palaeontology 14, 183-210. DOI 10.1080/14772019.2015.1030128

Liu, P., Xiao, S., Yin, C., Zhou, C., Gao, L. \& Tang, F. 2008. Systematic description and phylogenetic affinity of tubular microfossils from the Ediacaran Doushantuo Formation at Weng'an, South China. Palaeontology 51, 339-366. DOI 10.1111/j.1475-4983.2008.00762.x

Luchinina, V.A. 1995. Calcibionta, 180-194. In Pospelov, A.G., Pelman, Yu.L., Zhuravleva, I.T., Luchinina, V.A., Kuznetsova, V.G., Esakova, N.V., Ermak, V.V. \& Aksarina, N.A. 1995. Biostratigraphy of the Kiya River section. Annales de Paléontologie 81, 169-246.

Luchinina, V.A. \& Terleev, A.A. 2008. The morphology of the genus Epiphyton Bornemann. Geologica Croatica 61, 105-111. DOI 10.1134/S003103011414007X

Luchinina, V.A. \& Terleev, A.A. 2014. Features of Calcareous Algae Mineralization at the Transition to the Phanerozoic Biosphere. Paleontological Journal 48, 1450-1456.

Luchinina, V.A. \& Tiкhomirova, N.S. 1988. On new preservation forms of Early Cambrian algae and their ultrastructure, 112-114. In Dubatolov, V.N. \& Moskalenko, T.A. (eds) Izvestkovye vodorosli i stromatolity: sistematika, biostratigrafiya, fatsialnyj analiz: Sbornik nauchnykh trudov. 230 pp. Nauka, Novosibirsk.

Luo, H., Jiang, Z., Wu, X., Song, X., Ouyang, L. et al. 1982. The Sinian-Cambrian boundary in eastern Yunnan, China. 154 pp. Peoples' Publishing House, Yunnan. [in Chinese]

Mamet, B. \& Roux, A. 1975. Algues dévoniennes et carbonifères de la Téthys occidentale. Revue de Micropaléontologie 18, 134-187.

Mankiewicz, C. 1992a. Obruchevella in the Middle Cambrian Burgess Shale: preservation and taxonomic affinity. Journal of Paleontology 66, 717-729. DOI 10.1017/S0022336000020758

Mankiewicz, C. 1992b. Proterozoic and Early Cambrian Calcareous Algae, 981-998. In Schopf, J.W. \& Klein, C. (eds) The Proterozoic biosphere. 1348 pp. Cambridge University Press, Cambridge.

MASLOv, V.P. 1956. Iskopaemye izvestkovye vodorosli SSSR. Akademija Nauk SSSR, Trudy Geologitscheskogo Instituta 160, 1-302.

McMenamin, M.A.S. 2016. Dynamic Paleontology. 251 pp. Springer Geology, Dordrecht. DOI 10.1007/978-3-319-22777-1

Muscente, A.D., Hawkins, A. \& Xiao, S. 2015. Fossil preservation through phosphatization and silicification in the Ediacaran Doushantuo Formation (South China): a comparative synthesis. Palaeogeography, Palaeoclimatology, Palaeoecology 434, 46-62.

DOI 10.1016/j.palaeo.2014.10.013

Nicholson, H.A. \& Etheridge JR., R. 1878. A monograph of the Silurian fossils of the Girvan district of Ayrshire with special reference to those contained in the "Gray Collection", vol. 1(1). 341 pp. Blackwood, Edinburgh.

Peel, J.S. 1988. Spirellus and related helically coiled microfossils (Cyanobacteria) from the Lower Cambrian of North Greenland. Rapport Grønlands Geologiske Undersøgelse 137, 5-32.

Peel, J.S. 2014. Failed predation, commensalism and parasitism on lower Cambrian linguliformean brachiopods. Alcheringa 39, 149-163. DOI 10.1080/03115518.2015.964055

Peel, J.S. 2017. The oldest pelmatozoan encrusted hardground and holdfasts from Laurentia (Cambrian Series 2-3). GFF 139, 195-204. DOI 10.1080/11035897.2017.1347196

Peel, J.S. \& Streng, M. 2015. A new middle Cambrian bradoriid arthropod from Greenland and western Canada. Journal of Paleontology 89, 96-102. DOI 10.1017/jpa.2014.8

Qian, Y. \& Bengtson, S. 1989. Palaeontology and biostratigraphy of the Early Cambrian Meishucunian Stage in Yunnan Province, South China. Fossils and Strata 24, 1-156.

Riding, R. 1979. Devonian calcareous algae. Special Papers in Palaeontology 23, 141-144.

Riding, R. 1991. Cambrian calcareous cyanobacteria and algae, 305-334. In Riding, R. (ed.) Calcareous algae and stromatolites. Springer Verlag, Berlin.

Riding, R. \& Voronova, L. 1982. Affinity of the Cambrian alga Tubomorphophyton and its significance for the Epiphytaceae. Palaeontology 25, 869-878.

Rowland, S.M. \& Gangloff, R.A. 1988. Structure and paleoecology of lower Cambrian reefs. Palaios 3, 111-135. DOI $10.2307 / 3514525$

Săsăran, E., Bucur, I.I., Pleș, G. \& Riding, R. 2014. Late Jurassic Epiphyton-like cyanobacteria: indicators of longterm episodic variation in marine bioinduced microbial calcification? Palaeogeography, Palaeoclimatology, Palaeoecology 401, 122-131. DOI 10.1016/j.palaeo.2014.02.026

SCHAFFner, J.H. 1909. The classification of plants, IV. The Ohio Naturalist 9, 446-455.

Schopf, J.W. 2012. The fossil record of Cyanobacteria, 15-36. In Whitton, B.A. (ed.) Ecology of Cyanobacteria II. Their diversity in space and time. 760 pp. Springer, Dordrecht.

Schopf, J.W. \& Klein, C. 1992. The Proterozoic biosphere. 1348 pp. Cambridge University Press, Cambridge. DOI 10.1017/CBO9780511601064

Singh, P. \& ShukLa, S.D. 1981. Fossils from the Lower Tal: their age and its bearing on the stratigraphy of the Lesser Himalaya. Geoscience Journal 2, 157-176.

Stanier, R.Y. 1974. Division I. The Cyanobacteria, 22. In Buchanan, R.E. \& GibBons, N.E. (eds) Bergey's manual of determinative bacteriology. $8^{\text {th }}$ edition. Williams \& Wilkins, Baltimore.

VINN, O. 2017. Early symbiotic interactions in the Cambrian. Palaios 32, 231-237. DOI 10.2110/palo.2016.092

Voronova, L.G 1976. Izvestkovye vodorosli pogranichnykh sloev dokembriya i kembriya Sibirskoj platformy, 3-85. In Voronova, L.G. \& Radionova, E.P. (eds) Vodorosli i Mikrofitolity Paleozoya. Akademija Nauk SSSR, Trudy Geologitscheskogo Instituta 294. 
Wang, H., Zhang, Z., Holmer, L.E., Hu, S., Wang, X., \& LI, G. 2012. Peduncular attached secondary tiering acrotretoid brachiopods from the Chengjiang fauna: implications for the ecological expansion of brachiopods during the Cambrian explosion: Palaeogeography, Palaeoclimatology, Palaeoecology 323, 60-67. DOI 10.1016/j.palaeo.2012.01.027

Wood, A. 1957. The type-species of the genus Girvanella (calcareous algae). Palaeontology 1, 22-28.
WronA, R. 2004. Cambrian microfossils from glacial erratics of King George Island, Antarctica. Acta Palaeontologica Polonica 49, 13-56.

Zhuravlev, A.Yu., Gaméz Vintaned, J.A. \& Ivantsov, A.Yu. 2011. Discussion of 'First finds of problematic Ediacaran fossil Gaojiashania in Siberia and its origin'. Geological Magazine 148, 329-333.

DOI 10.1017/S0016756810000749 